\title{
Physiological energetics of juvenile clams Ruditapes decussatus in a high $\mathrm{CO}_{2}$ coastal ocean
}

\author{
M $^{\mathrm{a}}$ José Fernández-Reiriz ${ }^{1, *}$, Pedro Range ${ }^{2}$, Xosé Antón Álvarez-Salgado ${ }^{1}$, \\ Uxio Labarta ${ }^{1}$ \\ ${ }^{1}$ Consejo Superior Investigaciones Científicas, Instituto de Investigaciones Marinas, Eduardo Cabello 6, 36208 Vigo, Spain \\ ${ }^{2}$ Centro de Ciências do Mar (CCMAR), Universidade do Algarve, Campus de Gambelas, 8005-139 Faro, Portugal
}

\begin{abstract}
Effects of coastal ocean acidification, other than calcification, were tested on juvenile clams Ruditapes decussatus during a controlled $\mathrm{CO}_{2}$ perturbation experiment. The carbonate chemistry of natural (control) seawater was manipulated by injecting $\mathrm{CO}_{2}$ to attain 2 reduced $\mathrm{pH}$ levels ( -0.4 and $-0.7 \mathrm{pH}$ units) as compared with the control seawater. After $87 \mathrm{~d}$ of exposure, we found that the acidification conditions tested in this experiment significantly reduced the clearance, ingestion and respiration rates, and increased the ammonia excretion rate of $R$. decussatus seeds. Reduced ingestion combined with increased excretion is generally associated with a reduced energy input, which will likely contribute to a slower growth of the clams in a future high $\mathrm{CO}_{2}$ coastal ocean. These results emphasize the need for management policies to mitigate the adverse effects of global change on aquaculture, which is an economically relevant activity in most coastal areas worldwide.
\end{abstract}

KEY WORDS: Ocean acidification $\cdot$ Sea water $\mathrm{pH} \cdot$ Physiological energetics $\cdot$ Clams $\cdot$ Ruditapes decussatus Resale or republication not permitted without written consent of the publisher

\section{INTRODUCTION}

The oceans have dissolved up to $50 \%$ of the anthropogenic $\mathrm{CO}_{2}$ released to the atmosphere by the combustion of fossil fuels, contributing to partial mitigation of global warming (Sabine et al. 2004). However, the dissolution of anthropogenic $\mathrm{CO}_{2}$ has dramatically altered the inorganic carbon chemistry of seawater by reducing the carbonate ion saturation and the $\mathrm{pH}$ (Feely et al. 2004, Orr et al. 2005). Furthermore, simulations based on ocean circulation models predict an increase in atmospheric $\mathrm{CO}_{2}$ levels up to $2000 \mathrm{ppm}$ by the year 2300 and a corresponding decrease in surface ocean $\mathrm{pH}$ by 0.77 units (Caldeira \& Wickett 2003). The global coastal ocean, which occupies less than $10 \%$ of the total ocean surface (Wollast 1998) but provides more than $90 \%$ of global fish catches (Pauly \& Christensen 1995, Lindeboom 2002), is particularly sensitive to ocean acidification. About $10 \%$ of the global ocean pelagic, and $80 \%$ of the benthic, mineralization occurs in the coastal ocean (Middelburg et al. 1993, Wollast
1998), contributing to extensive reduction of the dissolved oxygen, $\mathrm{pH}$ and carbonate ion concentration in the water column (Thomas et al. 2004, Fabry et al. 2008, Koch \& Gobler 2009). The upwelling of aged subsurface waters from the adjacent ocean, which are also relatively poor in oxygen and carbonate ion, helps to enhance this pattern; in fact, eastern boundary upwelling systems are significantly more acidic than the rest of the surface ocean (Hauri et al. 2009). In addition, the impact of continental runoff on the chemistry of the coastal ocean depends on the mineral composition of the drainage basins (Borges \& Gypens 2010). In general, a freshwater stream draining a silicate basin strongly affected by agricultural, industrial and human sewages would produce a decrease of dissolved oxygen, $\mathrm{pH}$ and carbonate ion concentration in the coastal ocean (Koch \& Gobler 2009). According to Salisbury et al. (2008), coastal upwelling and riverine discharges can increase the concentration of $\mathrm{CO}_{2}$ in coastal waters to values in excess of $1000 \mathrm{ppm}$ and with sub-saturating levels of carbonate ion. Dissolved 
oxygen, pH and carbonate ion levels in temperate coastal waters are usually minimal during summer, when the biogenic materials produced during the preceding phytoplankton spring bloom have decomposed and many species of bivalves are spawning (Amaral 2009). In the particular case of the Iberian upwelling system (SW Europe), a significant reduction of the intensity and extension of the upwelling-favourable season has been observed over the last 50 yr (Lemos \& Sansó 2006), which has produced a duplication of the residence time of water in the Galician rias, a group of large coastal embayments of the northern coast (Álvarez-Salgado et al. 2008), and a concomitant enhancement of mineralization (Pérez et al. 2010).

Previous studies have shown that reductions in $\mathrm{pH}$ and in the concentration of carbonate ion in oceanic and coastal waters can have a negative effect on marine organisms (Fabry et al. 2008), eventually affecting their survival (Raven et al. 2005). However, a recent review by Hendriks et al. (2010) proposed that marine biota may be more resistant to acidification than expected. Most of the research efforts on this issue have been focused on the exploitable marine calcifiers with a special emphasis on the impact of ocean acidification on calcification rates (Orr et al. 2005, Gazeau et al. 2007, McDonald et al. 2009, Miller et al. 2009). For the particular case of marine bivalves, Michaelidis et al. (2005) and Berge et al. (2006) reported reduced growth rates for Mytilus spp. reared under conditions of increased $\mathrm{CO}_{2}$ and reduced $\mathrm{pH}$. Furthermore, Michaelidis et al. (2005) also showed that a prolonged reduction of seawater $\mathrm{pH}$ produces decreased respiration rates, increased protein degradation and acidosis of the haemolymph, which is buffered by the dissolution of the $\mathrm{CaCO}_{3}$ shell. More recent studies have shown that current and future increases in $\mathrm{CO}_{2}$ concentrations may deplete or alter the composition of shellfish populations in coastal ecosystems (Bibby et al. 2008, Kurihara, 2008, Miller et al. 2009, Talmage \& Gobler 2009).

Given that bivalves dominate the macrofauna of many estuarine and coastal marine systems, understanding their physiological behaviour is crucial for determining the productivity and energy flows in these animals. Expected changes in environmental variables can affect physiological processes in bivalves, modifying the impact of these organisms in the ecosystem. These effects need to be evaluated from an integrated perspective, given the important role these organisms play in terms of ecological structure and their value as economic resources for fisheries and aquaculture in many coastal areas. The potential for significant ecological and economic impacts arising from the effects of coastal ocean acidification on bivalves and the need for further research on commercially important species has been explicitly recognized (Fabry et al. 2008, Melaku Canu et al. 2010, J. A. Kleypas et al. unpubl. data).

The species targeted in the present study, the clam Ruditapes decussatus, is widely distributed in the Mediterranean and northeastern Atlantic, extending from Mauritania to the English Atlantic coast (Sobral \& Widdows 1997). Aquaculture and intensive harvesting of this species on natural banks occur mainly on the Iberian Peninsula, France and other Mediterranean countries (Amaral 2009). R. decussatus is the dominant aquaculture product from southern Portugal (Matias et al. 2009) and one of the most important species of clams in the fisheries and extensive aquaculture system of the Galician rias. Nevertheless, in recent decades the natural populations have been subject to overfishing, habitat loss, eutrophication and hypoxia and have consequently experienced a dramatic decrease (Amaral 2009). Important recovery efforts, such as new habitats, rehabilitation, transplant and sustainable fishing practices, are currently being implemented to increase the stocks of many species of bivalves. The experiments presented in this work were done on juvenile seed clams, which represent an important life stage for shellfish populations, as reductions in the growth and survival of seed have the potential to translate into declines of adult populations (Arnold 2008).

The present study focused on analyzing the effects of seawater acidification caused by increasing concentrations of $\mathrm{CO}_{2}$ on juvenile Ruditapes decussatus. Three levels of $\mathrm{pH}$ were tested: a natural (control) level and 2 levels reduced by -0.4 and -0.7 units, relative to the $\mathrm{pH}$ of the control seawater. The response of the clams was measured after $87 \mathrm{~d}$ of exposure to the 3 contrasting conditions, in terms of their key physiological parameters, particularly (1) clearance and ingestion rate; (2) oxygen consumption; (3) ammonia excretion; and (4) oxygen to nitrogen $(\mathrm{O}: \mathrm{N})$ ratio.

\section{MATERIALS AND METHODS}

Biological material. Individuals of Ruditapes decussatus were obtained from broodstock conditioned at an experimental bivalve hatchery in Tavira (Portugal) operated by the National Institute of Biological Resources (INRB, I.P./L-IPIMAR). At the beginning of the experiment, the clams were approximately $1 \mathrm{yr}$ old, ranging from 7 to $9 \mathrm{~mm}$ shell length, $4.3 \pm 0.3 \mathrm{mg}( \pm \mathrm{SD})$ dry weight $\left(100^{\circ} \mathrm{C}, 24 \mathrm{~h}\right)$ and $13.7 \pm 0.3 \%$ ash $\left(450^{\circ} \mathrm{C}\right.$, $24 \mathrm{~h})$.

pH acclimation system. Seawater was pumped from the Ria Formosa lagoon $\left(37^{\circ} 7^{\prime} 17.73^{\prime} \mathrm{N}\right.$, $\left.7^{\circ} 37^{\prime} 12.19^{\prime} \mathrm{W}\right)$, passed through a sand-filter and aer- 
ated for 2 to $3 \mathrm{~d}$ before entering the rearing system, to assure adequate oxygenation and stable $\mathrm{pH}$ during the acclimation period. Three levels of $\mathrm{pH}$ were tested: the natural seawater from Ria Formosa lagoon (control; $\Delta \mathrm{pH}=0)$ and 2 levels of reduced $\mathrm{pH}(\Delta \mathrm{pH}=-0.4$ and $\Delta \mathrm{pH}=-0.7$ units as compared with the control). Each level of $\mathrm{pH}$ had a separate $250 \mathrm{l}$ header tank and pump, supplying 3 replicate $15 \mathrm{l}$ plastic acclimation tanks. The seawater supply to the acclimation tanks was manually regulated using PVC valves. A flow-through system was used to minimize any interference from the metabolic waste products of the organisms. Excess water overflowed so that the volume in each tank was renewed 3 to 4 times per day.

Carbonate chemistry of seawater was manipulated in the reduced $\mathrm{pH}$ treatments by diffusing pure $\mathrm{CO}_{2}$ in open reactors (Aqua Medic - reactor 1000) installed before the acclimation tanks. The flux of gas from the pure $\mathrm{CO}_{2}$ bottles to the reactors was controlled through a pH-stat system (Aqua Medic AT Control) by opening or closing a solenoid valve when the $\mathrm{pH}$ readings in the acclimation tanks deviated from the predetermined set-points by $\pm 0.1 \mathrm{pH}$ units.

The acclimation period started on 7 July 2009, when each replicate tank ( 3 per pH level) was stocked with 100 juvenile clams. The $\mathrm{pH}$ of the acidified treatments was gradually reduced to the target values over the following 2 wk. The clams were fed with a 1:1 mixture of 2 microalgae strains, Tahitian Isochrysis aff. Galbana (T-ISO) and Chaetoceros calcitrans, supplied in continuous flow to each tank by a peristaltic pump (ISMATEC MPC Process) to maintain a concentration of 19 to 20 cells $\mu \mathrm{l}^{-1}$, equivalent to a total particulate matter load of $3.84 \mathrm{mg} \mathrm{l}^{-1}$ with $60 \%$ organic content. The seawater used for the preparation of the diet was filtered with a cartridge filter system with an effective pore size of $1 \mu \mathrm{m}$, and pre-treated with ultraviolet light. The diet was maintained in an aerated tank to generate a homogeneous mixture and prevent sedimentation.

Monitoring of the physico-chemical variables of seawater. Temperature, salinity and $\mathrm{pH}$ of seawater were continuously monitored during the experiment using dedicated electrodes and the data-logger function of the controller. Automatic readings were validated against regular manual determinations with a calibrated YSI 556 multi-probe. The pH electrodes were standardized against Tris seawater buffers (ionic strength of $0.7 \mathrm{M}$ ). Salinity readings were calibrated with an AutoSal salinometer using IAPSO (International Association for the Physical Sciences of the Oceans) standard seawater. Total alkalinity (TA) was determined twice during the acclimation period, on 20 July and 23 September 2009, by automatic titration with $\mathrm{HCl}$ past the endpoint of 4.5. Dissolved inorganic carbon (DIC), partial pressure of $\mathrm{CO}_{2}$ in seawater
$\left(\mathrm{pCO}_{2}\right)$ and the $\mathrm{CaCO}_{3}$ saturation state for calcite $(\Omega \mathrm{cal})$ and aragonite ( $\Omega$ ara) were calculated from in situ temperature and corrected $\mathrm{pH}$ and $\mathrm{TA}$, following the procedures described by Range et al. (2011).

Physiological experiments. The feeding behaviour and metabolic activity of Ruditapes decussatus were determined at the beginning of the acclimation period (Day 2), under natural $\mathrm{pH}$ conditions and after $87 \mathrm{~d}$ of acclimation at each of the 3 levels of $\mathrm{pH}$ considered $(\Delta \mathrm{pH}=0.0 ; \Delta \mathrm{pH}=-0.4 ;$ and $\Delta \mathrm{pH}=-0.7$ units $)$. Mortalities during the acclimation period varied among tanks (from 19 to $25 \%$ ) but the final shell length was $12.51 \pm$ $0.22 \mathrm{~mm}$ for all the $\mathrm{pH}$ treatments. Two size classes were distinguished after the acclimation, according to the modal size class (small: 10 to $13 \mathrm{~mm}$ and large: 14 to $20 \mathrm{~mm}$ shell length).

The physiological determinations of clearance, ingestion, respiration and excretion rates were always performed on 3 distinct pools of 5 (large) or 10 (small) individuals, for each combination of $\mathrm{pH}$ level and size class. Each pool was composed of randomly selected individuals (within each size class) from 1 of the 3 replicate acclimation tanks at each level of $\mathrm{pH}$. All the experiments were done using the same seawater supply and diet used during the acclimation period, thus ensuring that the relevant environmental conditions (temperature, salinity, pH and food supply) were maintained. Subsets of the clams used in the physiological determinations on Days 2 and 87 were subsequently sacrificed for determination of dry tissue $\left(100^{\circ} \mathrm{C}, 24 \mathrm{~h}\right)$ and organic weight $\left(450^{\circ} \mathrm{C}, 24 \mathrm{~h}\right)$. In all determinations, the physiological rates were also standardized to 1 unit of organic weight (specific rates).

Clearance (CR) and ingestion rates (IR). The CR was estimated from the reduction in suspended particle concentration, measured as volume of particles $\left(\mathrm{mm}^{3}\right.$ $\mathrm{l}^{-1}$ ), between the water surrounding the individuals and the outflow of the experimental chamber, following Filgueira et al. (2006). The clams (see 'Physiological experiments') were placed in a $300 \mathrm{ml}$ cylindrical chamber with a water inflow in the lower part and water outflow on the upper opposite side. The animals were placed in the chambers in such a way that the input flow was directed on the inhalant aperture and that the exhalant aperture was directed toward the water outflow, thus preventing re-filtration processes. For each $\mathrm{pH}$ level, 2 chambers without individuals served as a control for the calculation of the CR. The IR was calculated as the product of CR and food concentration.

Respiration rate $\left(\boldsymbol{V}_{\mathrm{O} 2}\right)$. Respiration rates were determined by incubating the clams in sealed $100 \mathrm{ml}$ Erlenmeyer flasks containing seawater at each $\mathrm{pH}$ studied (see 'Physiological experiments'). Temperature was maintained during the determinations by immersing 
the flasks in a isothermal bath. Two Erlenmeyers without animals were used as a control for each treatment. After approximately $30 \mathrm{~min}$ of incubation, when the valves of the individuals were opened, the dissolved oxygen concentration was monitored with a manual probe (HACH HQ40). The process was repeated until $\mathrm{O}_{2}$ concentrations fell below $30 \%$ of the initial value. Respiration rates were calculated from the difference in concentration between the chambers with and without animals, respectively.

Ammonia excretion rate $\left(\boldsymbol{V}_{\mathrm{NH} 4-\mathrm{N}}\right)$. Ammonia excretion rate was determined after placing the clams in open Erlenmeyer flasks with $250 \mathrm{ml}$ of filtered seawater (0.2 $\mathrm{mm}$ Millipore membranes) at each $\mathrm{pH}$ studied. Temperature was maintained during the measurements by immersing the flasks in an isothermal bath. Two Erlenmeyers without animals were used as a control for each treatment. After $90 \mathrm{~min}$, water samples were collected from each Erlenmeyer flask and frozen to $-20^{\circ} \mathrm{C}$ until analysis in the laboratory, according to the phenol-hypochlorite method described by Solorzano (1969). Ammonia excretion rates were calculated from the difference in ammonia concentration between the chambers with and without animals. The ratio of oxygen consumed to nitrogen excreted (O:N) was computed by atomic equivalents in accordance with Widdows (1985).

Statistical analysis. The effects of various factors ( $\mathrm{pH}$ and size) on the variation in physiological rates (clearance and ingestion rates, and metabolism) were compared using analyses of variance. Homogeneity of variance was confirmed by means of Bartlett's tests. When appropriate, multiple comparisons for means were carried out on significant main effects and interactions using Tukey's tests (Snedecor \& Cochran 1980, Zar 1984). Differences between means were considered statistically significant for $\mathrm{p}<0.05$.

\section{RESULTS}

\section{Physico-chemical characteristics of the seawater supply}

The pH-stat system was generally effective in maintaining 3 clearly distinct levels of $\mathrm{pH}$ during the acclimation and experimental periods. There were, however, some consistent deviations in the observed $\mathrm{pH}$ values from the planned differences between control and reduced $\mathrm{pH}$ levels during the acclimation period (Fig. 1). The carbonate chemistry of seawater in the 3 treatments is summarized in Table 1. Note that natural $\mathrm{pCO}_{2}$ levels of the Ria Formosa lagoon waters

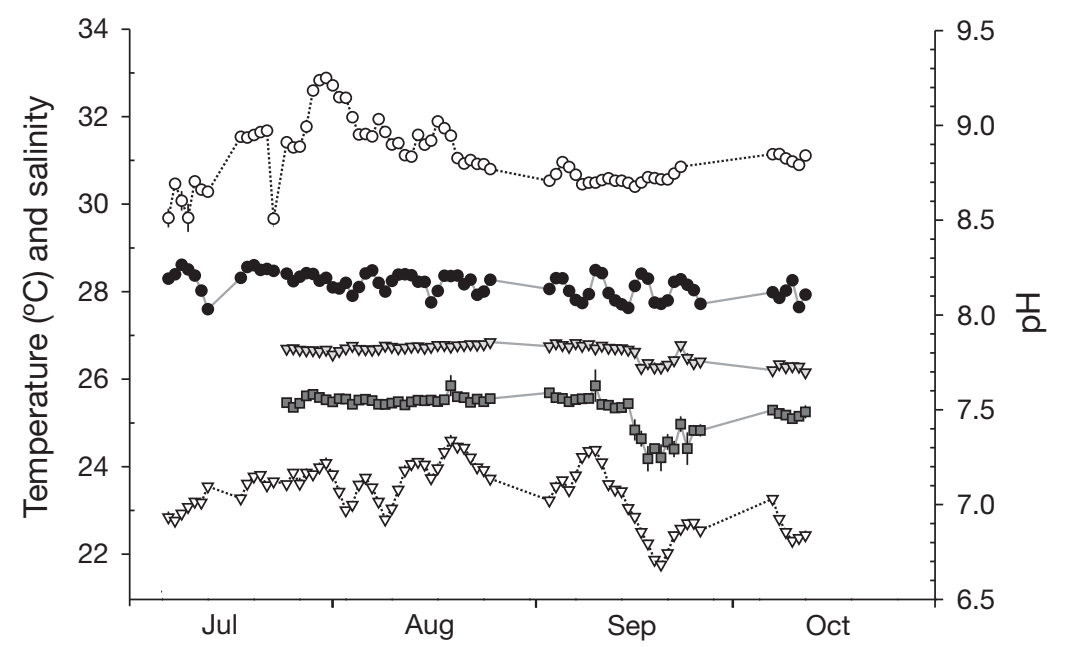

Fig. 1. Daily values (mean $\pm \mathrm{SE}$ ) for physico-chemical variables of seawater during the acclimation period; ( $(\circ)$ salinity, $(\bullet) \Delta \mathrm{pH}=0.0,(\vee) \Delta \mathrm{pH}=-0.4,(\square) \Delta \mathrm{pH}=$ -0.7 and $(\nabla)$ temperature

Table 1. Seawater carbonate chemistry variables (mean \pm SE) during the acclimation period. Temperature, salinity and total alkalinity (TA) were measured on each sampling date. $\mathrm{pH}$ was measured continuously during the experiment. Dissolved inorganic carbon (DIC), partial pressure of $\mathrm{CO}_{2}$ in seawater $\left(\mathrm{pCO}_{2}\right)$ and saturation state for calcite $(\Omega \mathrm{cal})$ and aragonite $(\Omega$ ara) were calculated from in situ temperature, corrected $\mathrm{pH}$ and TA. $\mathrm{pH}$ level: -0.4 and -0.7 indicate reduction in $\mathrm{pH}$ level as compared with control (CT). n: no. of tanks from each treatment sampled on each date

\begin{tabular}{|c|c|c|c|c|c|c|c|c|}
\hline $\mathrm{pH}$ level & $\begin{array}{c}\text { Temperature } \\
\left({ }^{\circ} \mathrm{C}\right)\end{array}$ & Salinity & $\mathrm{pH}$ & $\begin{array}{c}\text { TA } \\
\left(\mu \mathrm{mol} \mathrm{kg}{ }^{-1}\right)\end{array}$ & $\begin{array}{c}\text { DIC } \\
\left(\mu \mathrm{mol} \mathrm{kg}{ }^{-1}\right)\end{array}$ & $\begin{array}{l}\mathrm{pCO}_{2} \\
\text { ( } \mu \text { atm) }\end{array}$ & $\Omega$ cal & Sara \\
\hline \multicolumn{9}{|c|}{$20 \mathrm{Jul} 2009(\mathrm{n}=1)$} \\
\hline $\mathrm{CT}$ & 22.97 & 30.59 & 8.13 & 3917 & 3551 & 805 & 7.86 & 5.13 \\
\hline-0.4 & & & 7.84 & 3890 & 3727 & 1698 & 4.27 & 2.78 \\
\hline-0.7 & & & 7.46 & 3902 & 3934 & 4345 & 1.91 & 1.25 \\
\hline \multicolumn{9}{|c|}{$23 \operatorname{Sep} 2009(n=3)$} \\
\hline $\mathrm{CT}$ & $21.60 \pm 0.06$ & $31.36 \pm 0.31$ & $8.16 \pm 0.02$ & $3910 \pm 3$ & $3500 \pm 15.1$ & $730 \pm 36$ & $8.61 \pm 0.26$ & $5.64 \pm 0.17$ \\
\hline-0.4 & & & $7.82 \pm 0.02$ & $3920 \pm 3$ & $3749 \pm 8.4$ & $1813 \pm 71$ & $4.44 \pm 0.14$ & $2.91 \pm 0.09$ \\
\hline-0.7 & & & $7.53 \pm 0.04$ & $3911 \pm 6$ & $3895 \pm 24.6$ & $3702 \pm 345$ & $2.41 \pm 0.19$ & $1.58 \pm 0.12$ \\
\hline
\end{tabular}


were about twice the current atmospheric $\mathrm{pCO}_{2}$ levels. This means that the Ria Formosa lagoon acted as a net source of $\mathrm{CO}_{2}$ to the atmosphere during the experimental period. The elevated $\mathrm{pCO}_{2}$ and $\mathrm{pH}$ of the pumped water was maintained by its extremely high TA, which kept $\Omega$ cal and $\Omega$ ara above the $100 \%$ saturation threshold in the 3 treatments (Table 1). For more details, see Range et al. (2011).

\section{Physiological parameters}

The physiological parameters determined for the clams before the acclimation to 3 levels of pH are shown in Table 2 .

\section{Clearance and ingestion rates}

The 2-way ANOVA showed a significant effect of $\mathrm{pH}$ and size on the clearance and ingestion rates of Ruditapes decussates juveniles. Size was the factor that explained most of the variance: 74.3 and $63.6 \%$ for both rates, respectively (Table 3).

The 1-way ANOVA and Tukey's post-hoc test comparing both size classes (10 to $13 \mathrm{~mm}$ and 14 to $20 \mathrm{~mm}$ ) at the $3 \mathrm{pH}$ values studied showed that the CR and IR were significantly affected by size $(\mathrm{p}<0.01)$ in all treatments. For the large individuals (14 to $20 \mathrm{~mm}$ ), the clearance and ingestion rate of the clams differed significantly between the control $\mathrm{pH}$ and the reduced $\mathrm{pH}$ treatments (Table 2). The highest values for CR and IR were observed in large clams acclimatized at the control $\mathrm{pH}\left(624.3 \mathrm{ml} \mathrm{h}^{-1}\right.$ and $391.4 \mu \mathrm{g}$ organic weight [OW] $\mathrm{h}^{-1}$, respectively). For small clams, the clearance and ingestion rates in the extreme acidification treatment $(\Delta \mathrm{pH}=-0.7)$ were significantly lower than for the other $\mathrm{pH}$ levels $(\Delta \mathrm{pH}=-0.4$ and $\Delta \mathrm{pH}=0.0)$, which did not differ from each other $(\mathrm{p}>0.05)$. The largest specific clearance and ingestion rates were observed in small clams (10 to $13 \mathrm{~mm}$ ) acclimatized at $\Delta \mathrm{pH}=-0.4$ and $\Delta \mathrm{pH}=0.0$.

\section{Respiration rate $\left(V_{\mathrm{O} 2}\right)$}

The 2-way ANOVA showed that only the $\mathrm{pH}$ exerted a significant effect on the oxygen consumption $\left(\mathrm{ml} \mathrm{O}_{2} \mathrm{~h}^{-1}\right)$ of Ruditapes decussatus juveniles. This factor explains $33.2 \%$ of the total variance (Table 3).

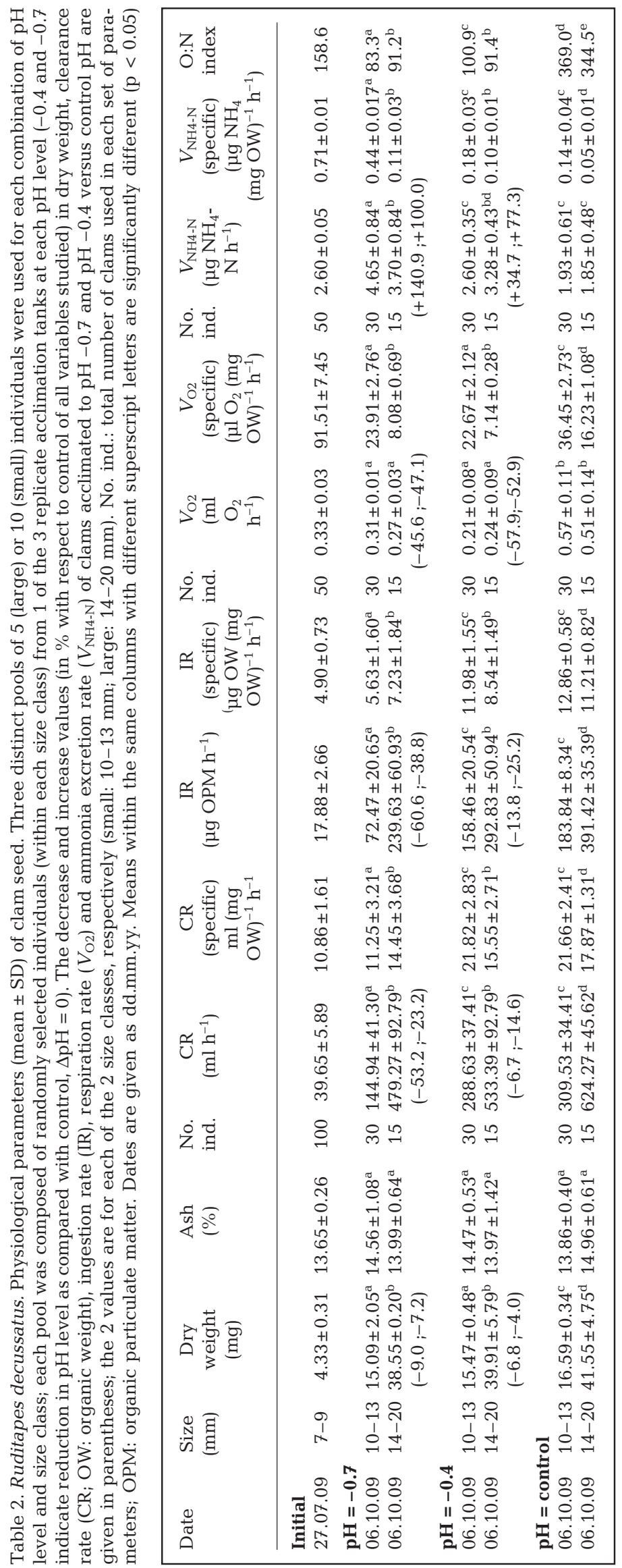


Table 3. Ruditapes decussatus. 2-way ANOVA testing the physiological parameters in clams acclimated with different $\mathrm{pH}$ values. $\mathrm{ns}=$ not significant $;{ }^{*} \mathrm{p}<0.05{ }^{*}{ }^{* *} \mathrm{p}<0.01 ;{ }^{* * *} \mathrm{p}<$ 0.001

\begin{tabular}{|c|c|c|c|c|}
\hline Source & $\begin{array}{l}\text { Sum of } \\
\text { squares }\end{array}$ & $\mathrm{df}$ & $\begin{array}{l}\text { Mean } \\
\text { square }\end{array}$ & $F$-ratio \\
\hline \multicolumn{5}{|l|}{ Dry weight } \\
\hline $\mathrm{pH}$ & $36.0 \times 10^{-3}$ & 2 & $18.0 \times 10^{-3}$ & $3.7^{*}$ \\
\hline Size & 4.0 & 1 & 4.0 & $846.8^{* * *}$ \\
\hline $\mathrm{pH} \times$ Size & $3.0 \times 10^{-3}$ & 2 & $2.0 \times 10^{-3}$ & $0.7 \mathrm{~ns}$ \\
\hline Error & $57.0 \times 10^{-3}$ & 12 & $5.0 \times 10^{-3}$ & \\
\hline \multicolumn{5}{|c|}{ Clearance rate } \\
\hline $\mathrm{pH}$ & $85.6 \times 10^{3}$ & 2 & $42.7 \times 10^{3}$ & $9.2^{* *}$ \\
\hline Size & $410.2 \times 10^{3}$ & 1 & $410.2 \times 10^{3}$ & $87.9^{* * *}$ \\
\hline $\mathrm{pH} \times$ Size & $7.3 \times 10^{3}$ & 2 & $3.7 \times 10^{3}$ & $0.8 \mathrm{~ns}$ \\
\hline Error & $56.0 \times 10^{3}$ & 12 & $4.7 \times 10^{3}$ & \\
\hline \multicolumn{5}{|c|}{ Ingestion rate organic } \\
\hline $\mathrm{pH}$ & $57.0 \times 10^{3}$ & 2 & $28.5 \times 10^{3}$ & $23.2^{* * *}$ \\
\hline Size & $136.0 \times 10^{3}$ & 1 & $136.0 \times 10^{3}$ & $111.0^{* * *}$ \\
\hline $\mathrm{pH} \times$ Size & $5.9 \times 10^{3}$ & 2 & $3.0 \times 10^{3}$ & $2.4 \mathrm{~ns}$ \\
\hline Error & $14.7 \times 10^{3}$ & 12 & $1.2 \times 10^{3}$ & \\
\hline \multicolumn{5}{|c|}{ Respiration rate $\left(V_{\mathrm{O} 2}\right)$} \\
\hline $\mathrm{pH}$ & $335.0 \times 10^{-3}$ & 2 & $168.0 \times 10^{-3}$ & $29.8^{* * *}$ \\
\hline Size & $0.0 \times 10^{-3}$ & 1 & $0.0 \times 10^{-3}$ & $0.0 \mathrm{~ns}$ \\
\hline $\mathrm{pH} \times$ Size & $7.0 \times 10^{-3}$ & 2 & $3.0 \times 10^{-3}$ & $0.6 \mathrm{~ns}$ \\
\hline Error & $68.0 \times 10^{-3}$ & 12 & $6.0 \times 10^{-3}$ & \\
\hline \multicolumn{5}{|c|}{ Ammonia excretion rate $\left(V_{\mathrm{NH} 4-\mathrm{N}}\right)$} \\
\hline $\mathrm{pH}$ & 23.2 & 2 & 11.6 & $74.7^{* * *}$ \\
\hline Size & 0.1 & 1 & 0.1 & $0.6 \mathrm{~ns}$ \\
\hline $\mathrm{pH} \times$ Size & 13.0 & 2 & 6.5 & $41.8^{* * *}$ \\
\hline Error & 1.8 & 12 & 0.1 & \\
\hline \multicolumn{5}{|l|}{ O:N index } \\
\hline $\mathrm{pH}$ & $100.4 \times 10^{3}$ & 2 & $50.2 \times 10^{3}$ & $73.5 \times 10^{3 * * *}$ \\
\hline Size & $0.1 \times 10^{3}$ & 1 & $0.1 \times 10^{3}$ & $0.2 \times 10^{3 * * *}$ \\
\hline $\mathrm{pH} \times$ Size & $0.5 \times 10^{3}$ & 2 & $0.2 \times 10^{3}$ & $0.3 \times 10^{3 * * *}$ \\
\hline Error & 8.2 & 12 & 0.6 & \\
\hline
\end{tabular}

The 1-way ANOVA (Table 3) and Tukey's test (Table 2) indicate that the respiration rate of Ruditapes decussatus seed did not differ between the 2 reduced $\mathrm{pH}$ levels. Oxygen consumption of clams in both size classes did, however, differ significantly between the reduced $\mathrm{pH}$ treatments and the control treatment (approx. $0.26 \mathrm{ml}$ vs. $0.54 \mathrm{ml} \mathrm{O}_{2} \mathrm{~h}^{-1}$ ). A similar pattern was observed for the specific oxygen consumption $(\mu \mathrm{l}$ $\left.\mathrm{O}_{2}(\mathrm{mg} \mathrm{OW})^{-1} \mathrm{~h}^{-1}\right)$, with the largest values occurring for control $\mathrm{pH}$ for each of the 2 size classes considered (Table 2).

\section{Ammonia excretion rate $\left(V_{\mathrm{NH} 4-\mathrm{N}}\right)$}

The 2-way ANOVA showed a significant effect of $\mathrm{pH}$ and $\mathrm{pH}$-size interaction on the ammonia excretion rate $\left(V_{\mathrm{NH} 4-\mathrm{N}}\right)$ of Ruditapes decussatus juveniles (Table 3). Significant differences between the 2 size classes (Table 2, Tukey's test, $\mathrm{p}<0.01$ ) were observed for $R$. de- cussatus acclimated to the reduced $\mathrm{pH}$ treatments, but not for the control $\mathrm{pH}$ treatment. An inverse relation between $\mathrm{pH}$ level and ammonia excretion rate $\left(V_{\mathrm{NH} 4-\mathrm{N}}\right)$ was observed for both size classes, with minimal values for $\mathrm{pH}$ control and maximal values for $\Delta \mathrm{pH}=-0.7$. A similar trend was apparent for the specific ammonia excretion $\left(V_{\mathrm{NH} 4-\mathrm{N}}(\mathrm{mg} \mathrm{OW})^{-1} \mathrm{~h}^{-1}\right)$.

\section{$\mathrm{O}: \mathrm{N}$ index}

The 2-way ANOVA indicated a significant effect of $\mathrm{pH}$, size and $\mathrm{pH}$-size interaction on the O:N index of Ruditapes decussates juveniles (Table 3). The O:N index generally showed a consistent and significant increase with the $\mathrm{pH}$ level (Table 2, Tukey's test, $\mathrm{p}<$ 0.01), except for the largest size class, which did not differ between the 2 reduced $\mathrm{pH}$ treatments. There were significant differences between the 2 size classes for all $\mathrm{pH}$ levels, although the direction of the effect was not the same: small individuals showed larger values in the control and $\Delta \mathrm{pH}=-0.4$ treatments, but the pattern was inverted in the $\Delta \mathrm{pH}=-0.7$ treatment. The largest values were observed for the smaller size class in the pH control treatment (approx. 369).

\section{DISCUSSION}

Atmospheric $\mathrm{pCO}_{2}$ values are generally used as guidelines in ocean acidification experiments, but the corresponding values for seawater carbonate chemistry are the primary measurements (Barry et al. 2010). In the present study, we have used the simplest approach to relate both of them, using published predictions of $\mathrm{pH}$ reductions and other changes in the carbonate chemistry of seawater estimated from changes in atmospheric $\mathrm{pCO}_{2}$ (e.g. Caldeira \& Wickett 2003, 2005, Feely et al. 2004, Orr et al. 2005). Although widely used, this approach has limitations and it is generally difficult to evaluate whether the $\mathrm{pH}$ reductions adopted are realistic at a local scale (Range et al. 2011). These concerns are particularly relevant in the coastal ocean, where the physico-chemical characteristics of seawater can be substantially different from those found in surface waters of offshore regions (Borges \& Gypens 2010, Ishimatsu \& Dissanayake 2010). Some valid alternatives have been proposed, but they require previous knowledge about seawater carbonate chemistry in the study area (Barry et al. 2010).

The most remarkable characteristic of the carbonate chemistry of the water from Ria Formosa is the extremely high TA of about $3900 \mu \mathrm{mol} \mathrm{kg}{ }^{-1}$. Although this value is within the range observed in inner coastal 
waters of the southern Iberian Peninsula (e.g. Cabeçadas \& Oliveira 2005, de la Paz et al. 2007), it greatly exceeds the TA value of $2300 \mu \mathrm{mol} \mathrm{kg} \mathrm{kg}^{-1}$ characteristic of the Eastern North Atlantic Central Water that upwells in this area (Castro et al. 2006), which is very close to the average open ocean value of $2325 \mu \mathrm{mol} \mathrm{kg}{ }^{-1}$ (Gattuso \& Lavigne 2009). This naturally elevated TA of seawater, probably associated with extremely alkaline continental runoff waters in excess of $13 \mathrm{mmol} \mathrm{kg}{ }^{-1}$, prevented under-saturation of $\mathrm{CaCO}_{3}$ in the $\mathrm{CO}_{2}$-acidified treatments, avoiding any significant impact of the carbonate supply side of calcification on the growth of the clams. Instead, as suggested in a recent study with lobster larvae that reported a similar buffering mechanism (Arnold et al. 2009), the physiological alterations observed here were most likely the result of acidosis or hypercapnia interfering with normal homeostatic function.

Our results show that the levels of seawater acidification tested in the present study ( $\mathrm{pH}$ reduced by 0.4 and 0.7 units as compared with the natural $\mathrm{pH}$ levels of the Ria Formosa lagoon) can significantly decrease the feeding behaviour (clearance and ingestion rates) of Ruditapes decussatus, a species of clam of great ecological and commercial relevance. Furthermore, the most extreme $\mathrm{pH}$ reduction was also associated with decreased respiration rates and increased ammonia excretion. Significant differences were also found in the $\mathrm{O}: \mathrm{N}$ index among clams acclimated to the 3 levels of $\mathrm{pH}$ tested, with the clams from control $\mathrm{pH}$ treatments showing the largest values. The values of the parameters of feeding behaviour and metabolism measured in the $R$. decussatus seed before exposure to seawater acidified with $\mathrm{CO}_{2}$ were similar to values observed in previous studies (M. J. Fernández-Reiriz unpubl. data).

The type of physiological response observed herereduced energetic input associated with increased rates of nitrogen excretion and decreased respiration rates (typical of environments with limited availability of oxygen) - is generally indicative of limited energy availability for growth and other physiological functions. In fact, a trend towards lower values for the dry and organic weights of the clams with decreasing $\mathrm{pH}$ is apparent from Table 2 . This pattern is more evident for the larger size class (14 to $20 \mathrm{~mm}$ shell length) if absolute values are considered but for the smaller size class (10 to $13 \mathrm{~mm}$ ) if percentages of change are considered. Bamber (1987) also reported reduced feeding activity and depression of flesh weight for juvenile Ruditapes decussatus under acidified conditions $(\mathrm{pH}<$ 7.0). However, he used seawater acidified with sulphuric acid and $\mathrm{pH}$ reductions that exceed all current predictions for ocean acidification, which limits the comparability and relevance of his results. Although non-significant differences in net calcification and growth rates were obtained by Range et al. (2011) with our experimental design, note that they did not differentiate between size classes.

According to Langenbuch \& Pörtner (2002), ammonia excretion rates cannot be seen independently of the respective rates of oxygen consumption and energy turnover, which are reduced during metabolic depression, because less protein or amino acids are being catabolized. Berge et al. (2006) reported growth reduction in acidified seawater and concluded that this is probably related to metabolic suppression, which has also been suggested to be an important biological impact caused by ocean storage of $\mathrm{CO}_{2}$ (Seibel \& Walsh 2003). According to Bayne \& Thompson (1970), a common response of organisms to stress is the use of reserves of nutrients to maintain metabolic requirements, which may have increased above normal values. The ratio between oxygen consumption and ammonia excretion rates, the O:N index, represents the proportion of protein in relation to lipids or carbohydrates catabolized for metabolic energy requirements. Accordingly, a high rate of protein catabolism compared to lipids or carbohydrates is expressed by a low ratio, which is generally indicative of a stressed condition (Kreeger 1993, Amaral 2009). Widdows (1985) demonstrated that index values below 30 lie on the stress threshold for Mytilus edulis. Amaral (2009), taking values below 30 as indicative of stress, found significant differences in the O:N ratio of Ruditapes decussatus from different locations within the Ria Formosa.

Other studies have shown some deleterious effects of $\mathrm{CO}_{2}$-induced acidification on bivalve molluscs. According to Pörtner et al. (2005), the ability to internally compensate during periods of acidosis incurs physiological and energetic cost such as decreased growth, respiration rate and protein synthesis. Similar to our results, Bamber (1990) reported suppression of feeding activity, growth suppression and loss of tissue weight for the marine bivalves Ostrea edulis, Crassostrea gigas and Mytilus edulis exposed to reduced seawater pH. Also, Michaelidis et al. (2005), working on the mussel Mytilus galloprovincialis, suggested that seawater acidification is associated with a reduction in respiration rate, as measured by a reduction in the rate of $\mathrm{O}_{2}$ consumption and increased excretion of ammonia, indicating net degradation of protein. Berge et al. (2006) found that decreased seawater $\mathrm{pH}$ reduced the growth of Mytilus edulis. Talmage \& Gobler (2009) showed that levels of atmospheric $\mathrm{CO}_{2}$ similar to those predicted for the 21st century may affect some species of bivalves (Mercenaria mercenaria) more than others (C. virginica). Similarly, Calabrese \& Davis (1966) had previously found increased tolerance to reduced $\mathrm{pH}$ 
for larvae of the oyster $C$. virginica relative to larvae of the clam Mercenaria mercenaria.

The effects of seawater acidification on the different physiological rates studied were consistently stronger for the extreme $\mathrm{pH}$ reduction $(-0.7 \mathrm{pH}$ units). The reductions in clearance (by -53.2 and $-23.2 \%$ ) and ingestion rates (by -60.6 and $-38.8 \%$ ) and the increased rates of ammonia excretion (by +140.9 and $+100.0 \%$ ) observed for Ruditapes decussatus seed acclimated in seawater acidified with $\mathrm{CO}_{2}$ could eventually affect future adult populations. Current rates of increase in atmospheric $\mathrm{CO}_{2}$ levels have been predicted to lead to a correspondent decrease in surface ocean $\mathrm{pH}$ by as much by $0.77 \mathrm{pH}$ units by 2300 (Caldeira \& Wickett 2003).

The present study has shown that juvenile Ruditapes decussatus are able to survive up to $87 \mathrm{~d}$ exposure to extreme reductions of seawater $\mathrm{pH}$ (up to 0.7 units), although some of their physiological parameters are affected. Accordingly, all rehabilitation efforts in the near future should also consider the capacity of the individuals to persist in environments with increased levels of $\mathrm{CO}_{2}$ (Beesley et al. 2008). A better understanding of the long-term effects of seawater acidification is also clearly needed, particularly with respect to changes in feeding behaviour, metabolism, growth and reproduction.

Acknowledgements. The authors acknowledge the following people for their help at various stages of this study: L. Nieto and B. Gonzalez for their valuable technical assistance; D. Matias, S. Joaquim and M. Ramos for producing the clam seed and microalgal food; D. Piló and M. Teixeira for maintaining the acclimation system. This is a contribution to the ACIDBIV project, which is part of the CIRCLE Med projects, funded by the Regional Ministry of Innovation and Industry of the Galician Government (08MDS018402PR), the Italian Ministry for Environment, Land and Sea, and the Foundation for Science and Technology of Portugal (ERA-CIRCLE/0004/ 2007), in the framework of the Circle ERA Net project (which is funded by the European Commission 6th Framework Programme).

\section{LITERATURE CITED}

Álvarez-Salgado XA， Labarta U, Fernández-Reiriz MJ, Figueiras FG and others (2008) Renewal time and the impact of harmful algal blooms on the extensive mussel raft culture of the Iberian coastal upwelling system (SW Europe). Harmful Algae 7:849-855

Amaral AMA (2009) Management of aquaculture of the clam, $R$. decussatus (Linnaeus, 1758) in the Ria Formosa lagoon (south of Portugal): effects on the ecosystem and species physiology. PhD thesis, Universidad de Santiago de Compostela

Arnold WS (2008) Application of larval release for restocking and stock enhancement of coastal marine bivalve populations. Rev Fish Sci 16:65-71

> Arnold KE, Findlay HS, Spicer JI, Daniels CL, Boothroyd D (2009) Effect of $\mathrm{CO}_{2}$-related acidification on aspects of the larval development of the European lobster, Homarus gammarus (L.). Biogeosciences 6:1747-1754

Bamber R (1987) The effects of acidic sea water on young carpet-shell clams Venerupis decussata (L.) (Mollusca: Veneracea). J Exp Mar Biol Ecol 108:241-260

Bamber NR (1990) The effects of acidic sea water on three species of lamellibranch molluscs. J Exp Mar Biol Ecol 143:181-191

Barry JP, Tyrrell T, Hansson L, Plattner GK, Gattuso JP 2010. Atmospheric $\mathrm{CO}_{2}$ targets for ocean acidification perturbation experiments. In: Riebesell U, Fabry VJ, Hansson L, Gattuso JP (eds) Guide to best practices for ocean acidification research and data reporting. Publications Office of the European Union, Luxembourg, p 53-66

Bayne BL, Thompson RJ (1970) Some physiological consequences of keeping Mytilus edulis in the laboratory. Helgol Wiss Meeresunters 20:526-552

Beesley A, Lowe DA, Pascoe CK, Widdicombe S (2008) Effects of $\mathrm{CO}_{2}$-induced seawater acidification on the health of Mytilus edulis. Clim Res 37:215-225

Berge JA, Bjerkeng B, Pettersen O, Schaanning MT, Oxnevad $S$ (2006) Effects of increased sea water concentrations of $\mathrm{CO}_{2}$ on growth of the bivalve Mytilus edulis. Chemosphere 62:681-687

Bibby R, Widdicombe S, Parry H, Spicer JI, Pipe R (2008) Impact of ocean acidification on the immune response of the blue mussel Mytilus edulis. Aquat Biol 2:67-74

Borges AV, Gypens N (2010) Carbonate chemistry in the coastal zone responds more strongly to eutrophication than to ocean acidification. Limnol Oceanogr 55:346-353

Cabeçadas L, Oliveira AP (2005) Impact of a Coccolithus braarudii bloom on the carbonate system of Portuguese coastal waters. J Nannoplankt Res 27:141-147

Calabrese A, Davis HC (1966) The pH tolerance of embryos and larvae of Mercenaria mercenaria and Crassostrea virginica. Biol Bull 131:427-436

Caldeira K, Wickett ME (2003) Anthropogenic carbon and ocean $\mathrm{pH}$. Nature 425:365

> Caldeira K, Wickett ME (2005) Ocean model predictions of chemistry changes from carbon dioxide emissions to the atmosphere and ocean. J Geophys Res Oceans 110: C09S04

- Castro CG, Nieto-Cid M, Álvarez-Salgado XA, Pérez FF (2006) Local mineralization in the mesopelagic zone of the Eastern North Atlantic, off the NW Iberian Peninsula. Deep-Sea Res 53:1925-1940

> de la Paz M, Gómez-Parra A, Forja J (2007) Inorganic carbon dynamic and air-water $\mathrm{CO}_{2}$ exchange in the Guadalquivir Estuary (SW Iberian Peninsula). J Mar Syst 68:265-277

$>$ Fabry VJ, Seibel BA, Feely RA, Orr JC (2008) Impacts of ocean acidification on marine fauna and ecosystem processes. ICES J Mar Sci 65:414-432

Feely RA, Sabine CL, Lee K, Berelson W, Kleypas J, Fabry VJ, Millero FJ (2004) Impact of anthropogenic $\mathrm{CO}_{2}$ on the $\mathrm{CaCO}_{3}$ system in the oceans. Science 305:362-366

Filgueira R, Labarta U, Fernández-Reiríz MJ (2006) Flowthrough chamber method for clearance rate measurements in bivalves: design and validation of individual chambers and mesocosm. Limnol Oceanogr Methods 4: 284-292

Gattuso J, Lavigne H (2009) Approaches and software tools to investigate the impact of ocean acidification. Biogeosciences 6:2121-2133

Gazeau F, Quiblier C, Jansen JM, Gattuso JP, Middelburg JJ, Heip CHR (2007) Impact of elevated $\mathrm{CO}_{2}$ on shellfish calcification. Geophys Res Lett 34: L07603

Hauri C, Gruber N, Plattner GK, Allin S, Feely RA, Hales B, 
Wheeler PA (2009) Ocean acidification in the California Current System. Oceanography (Wash DC) 22:60-71

Hendriks IE, Duarte CM, Álvarez M (2010) Vulnerability of marine biodiversity to ocean acidification: A meta-analysis. Estuar Coast Shelf Sci 86:157-164

Ishimatsu A, Dissanayake A (2010) Life threatened in acidic coastal waters. In: Ishimatsu A, Lie HJ (eds) Coastal environmental and ecosystem issues of the East China Sea. TERRAPUB and Nagasaki University, Tokyo, p 283-303

Koch R, Gobler CJ (2009) The effects of tidal export from salt marsh ditches on estuarine water quality and plankton communities. Estuar Coast 32:261-275

Kreeger DA (1993) Seasonal patterns in utilization of dietary protein by the mussel Mytilus trossulus. Mar Ecol Prog Ser 95:215-232

Kurihara $\mathrm{H}$ (2008) Effects of $\mathrm{CO}_{2}$-driven ocean acidification on the early developmental stages of invertebrates. Mar Ecol Prog Ser 373:275-284

Langenbuch M, Pörtner HO (2002) Changes in metabolic rate and $\mathrm{N}$ excretion in the marine invertebrate Sipunculus nudus under conditions of environmental hypercapnia: identifying effective acid-base variables. J Exp Biol 205: 1153-1160

Lemos RT, Sansó B (2006) Spatio-temporal variability of ocean temperature in the Portugal Current System. J Geophys Res Oceans 111:C04010. doi:10.1029/2005JC003051

Lindeboom $H$ (2002) The coastal zone: an ecosystem under pressure. In: Field JG, Hempel G, Summerhayes CP (eds) Oceans 2020: Science, trends and the challenge of sustainability. Island Press, Covelco, CA, p 49-84

Matias D, Joaquim S, Leitão A, Massapina C (2009) Effect of geographic origin, temperature and timing of broodstock collection on conditioning, spawning success and larval viability of Ruditapes decussatus (Linné, 1758). Aquacult Int 17:257-271

McDonald MR, McClintock JB, Amsler CD, Rittschof D, Angus RA, Orihuela B, Lutostanski K (2009) Effects of ocean acidification over the life history of the barnacle Amphibalanus Amphitrite. Mar Ecol Prog Ser 385: 179-187

Melaku Canu D, Solidoro C, Cossarini G, Giorgi F (2010) Effect of global change on bivalve rearing activity and the need for adaptive management. Clim Res 42:13-26

Michaelidis B, Ouzounis C, Paleras A, Pörtner HO (2005) Effects of long-term moderate hypercapnia on acid-base balance and growth rate in marine mussels Mytilus galloprovincialis. Mar Ecol Prog Ser 293:109-118

Middelburg JJ, Vlug T, Jaco F, van der Nat WA (1993) Organic matter mineralization in marine systems. Global Planet Change 8:47-58

Miller AW, Reynolds AC, Sobrino C, Riedel GF (2009) Shellfish face uncertain future in high $\mathrm{CO}_{2}$ world: influence of acidification on oyster larvae and growth in estuaries. PLoS ONE 4(5) e5661

Orr JC, Fabry VJ, Aumont O, Bopp L and others (2005) Anthropogenic ocean acidification over the twenty-first century and its impact on calcifying organisms. Nature

Editorial responsibility: James McClintock, Birmingham, Alabama, USA
437:681-686

Pauly D, Christensen V (1995) Primary production required to sustain global fisheries. Nature 374:255-257

Pérez FF, Padín XA, Pazos Y, Gilcoto M and others (2010) Plankton response to weakening of the Iberian coastal upwelling. Global Change Biol 16:1258-1267

> Pörtner HO, Langenbuch M, Michaelidis B (2005) Synergistic effects of temperature extremes, hypoxia, and increases in $\mathrm{CO}_{2}$ on marine animals: from Earth history to global change. J Geophys Res 110:C09510, doi:10.1029/ 2004JC002561

Range P, Chicharo MA, Ben-Hamadou R, Piló D and others (2011) Calcification, growth and mortality of juvenile clams Ruditapes decussatus under increased $\mathrm{pCO}_{2}$ and reduced $\mathrm{pH}$ : variable responses to ocean acidification at local scales? J Exp Mar Biol Ecol 396:177-184

Raven J, Caldeira K, Elderfield H, Hoegh-Guldberg $\mathrm{O}$ and others (2005) Ocean acidification due to increasing atmospheric carbon dioxide. The Royal Society Policy Document 12/05. Clyvedon Press, Cardiff

Sabine CL, Feely RA, Gruber N, Key RM and others (2004) The oceanic sink for anthropogenic $\mathrm{CO}_{2}$. Science 305: $367-371$

Salisbury J, Green M, Hunt C, Campbell J (2008) Coastal acidification by rivers: a new threat to shellfish? EOS Trans Am Geophys Union 89:513

Seibel BA, Walsh PJ (2003) Biological impacts of deep-sea carbon dioxide injection inferred from indices of physiological performance. J Exp Biol 206:641-650

Snedecor GW, Cochran WG (1980) Statistical methods. Iowa State University Press, Ames, IA

Sobral P, Widdows J (1997) Effects of elevated temperatures on the scope for growth and resistance to air exposure of the clam $R$. decussatus (L.) from southern Portugal. Sci Mar 61:163-171

Solorzano L (1969) Determination of ammonia in natural waters by the phenolhypochlorite method. Limnol Oceanogr 14:799-801

> Talmage SC, Gobler CJ (2009) The effects of elevated carbon dioxide concentrations on the metamorphosis, size and survival of larval hard clams (Mercenaria mercenaria), bay scallops (Argopecten irradians), and Eastern oysters (Crassostrea virginica). Limnol Oceanogr 54:2072-2080

Thomas H, Bozec Y, Elkaray K, de Baar HJW (2004) Enhanced open ocean storage of $\mathrm{CO}_{2}$ from shelf sea pumping. Science 304:1005-1008

Widdows J (1985) Physiological measurements. In: Bayne BL, Brown DA, Burns K, Dixon DR and others (eds) The effects of stress and pollution on marine animals. Praeger, New York, NY, p 3-45

Wollast R 1998. Evaluation and comparison of the global carbon cycle in the coastal zone and in the open ocean. In: Brink KH, Robinson AR (eds) The global coastal ocean, processes and methods. The sea, Vol 10. John Wiley, New York, NY, p 213-252

Zar JH (1984) Biostatistical analysis. Prentice Hall, Englewood Cliffs, NJ

Submitted: June 17, 2010; Accepted: January 28, 2011 Proofs received from author(s): June 6, 2011 